\title{
Diminished Clostridium difficile Toxin A Sensitivity in Newborn Rabbit lleum Is Associated with Decreased Toxin A Receptor
}

\author{
Richard Eglow, Charalabos Pothoulakis, Steven Itzkowitz, * Esther Jacobowitz Israel, ${ }^{\star}$ Connor J. O’Keane, Dahai Gong, \\ Ning Gao, Yung L. Xu, W. Allan Walker, ${ }^{\star}$ and J. Thomas LaMont \\ Sections of Gastroenterology and Department of Pathology, University Hospital, Boston University School of Medicine, Boston, \\ Massachusetts 02118; and *The Mount Sinai Medical Center, and Division of Pediatric Gastroenterology, The Massachusetts General \\ Hospital, ${ }^{\ddagger}$ Harvard Medical School, Boston, Massachusetts 02115
}

\begin{abstract}
Human infants are relatively resistant to Clostridium difficileassociated diarrhea and colitis compared to adults. In that toxin $A$ is the major cause of intestinal damage with this organism, we compared toxin A receptor binding and biological effects in newborn vs adult rabbit ileum. Purified toxin A $\left(M_{\mathrm{r}} 308 \mathrm{kD}\right)$ was labeled with tritium or biotin with full retention of biologic activity. Appearance of specific toxin A brush border (BB) binding was strongly age dependent with minimal $\left[{ }^{3} \mathrm{H}\right]$ toxin $A$ specific binding at 2 and $5 \mathrm{~d}$ of life, followed by gradual increase in binding to reach adult levels at 90 d. Absence of toxin $A$ binding sites in newborn and presence in adult rabbits was confirmed by immunohistochemical studies using biotinylated toxin A. Toxin A (50 ng to $20 \mu \mathrm{g} / \mathrm{ml}$ ) inhibited protein synthesis in 90-d-old rabbit ileal loops in a dose-dependent fashion. In contrast, inhibition of protein synthesis in 5-d-old rabbit ileum occurred only at the highest toxin A doses (5 and $20 \mu \mathrm{g} / \mathrm{ml}$ ) and at all doses tested was significantly less than the adult rabbit ileum. In addition, toxin $A(5 \mu \mathrm{g} / \mathrm{ml})$ caused severe mucosal damage in adult rabbit ileal explants but had no discernable morphologic effect on 5-d-old rabbit intestine. Our data indicate that newborn rabbit intestine lacks $B B$ receptors for toxin A. The absence of the high-affinity BB receptor for toxin $A$ in the newborn period may explain lack of biologic responsiveness to purified toxin, and the absence of disease in human infants infected with this pathogen. (J. Clin. Invest. 1992. 90:822-829.) Key words: brush border receptor • Clostridium difficile • development • enterotoxin A • toxin receptor
\end{abstract}

\section{Introduction}

Clostridium difficile has emerged as the most important cause of antibiotic-associated colitis in animals $(1,2)$ and humans ( 3 , 4 ) and is one of the most commonly diagnosed nosocomial

This work was presented in part at the 89th Annual Meeting of the American Gastroenterological Association, Washington, DC, and the 90th Annual Meeting of the American Gastroenterological Association, San Antonio, TX, and published in abstract form (1989. Gastroenterology. 96:A136; 1990. Gastroenterology. 98:A446).

Address reprint requests to Dr. LaMont, Department of Gastroenterology, University Hospital, Boston University Medical Center, 88 East Newton Street, Boston, MA 02118.

Received for publication 28 October 1991 and in revised form 10 April 1992.

J. Clin. Invest.

(C) The American Society for Clinical Investigation, Inc. 0021-9738/92/09/0822/08 \$2.00

Volume 90, September 1992, 822-829 infections (5). This gram-positive obligate anaerobe produces two protein exotoxins: toxin A and toxin B. Toxin A is a 308$\mathrm{kD}(6)$ enterotoxin that elicits intestinal fluid secretion and inflammation, causes severe destruction of villi, and increases permeability in adult rabbit and guinea pig ileum (7-10). In addition to its enterotoxic activity, toxin A also possess cytotoxic activity against several intestinal and nonintestinal cultured cells (11-13), and hemagglutinating activity against rabbit erythrocytes (14). Toxin B is a potent cytotoxin, but possesses no enterotoxic activity in hamster or rabbit intestine $(7$, $8,15)$.

A curious, and thus far unexplained, aspect of $C$. difficile infection is the relative resistance of human newborns and infants to this pathogen. When adults and children older than 2 $\mathrm{yr}$ of age are infected with toxigenic strains of this pathogen, they generally exhibit signs and symptoms of enterocolitis, although newborns and infants may harbor this pathogen and its toxins in their intestines without developing evidence of disease. Indeed, $C$. difficile and its toxins can be identified in the feces of up to $70 \%$ of healthy neonates and infants $(16,17)$, often at levels similar to those recorded in adults with severe antibiotic-associated colitis $(16,18)$. The reason(s) for this apparent "resistance" is unknown, but several investigators have suggested that it may be related to diminished toxin A receptors in infants $(16,19)$, as has been reported for the shigella toxin receptor (20).

As with other bacterial exotoxins, membrane receptors for toxin $\mathrm{A}$ are thought to be required for intoxication of target cells $(21,22)$. Krivan et al. (14) and Clark et al. (23) showed that the toxin A receptor in rodents is a glycoconjugate containing the trisaccharide $\mathrm{Gal} \alpha 1-3 \mathrm{Gal} \beta 1-4 \mathrm{GlcNAc}$. Interestingly, toxin A binding (14), hemagglutination (14), and cytotoxicity (21) could be blocked by prior exposure of cells to Bandeirea simplicifolia (BS-1) ${ }^{1}$ lectin, a plant lectin which binds specifically to glycolipids and glycoproteins containing $\alpha$-D-galactose residues and hemagglutinates rabbit erythrocytes (14). Although the toxin A receptor on rabbit erythrocytes appears to be a glycolipid (23), we have recently reported that the toxin A receptor on the rabbit ileal brush border $(\mathrm{BB})$ is a protease-sensitive glycoprotein containing $\alpha$-D-galactose (24). A single class of toxin A receptors was found with a $K_{\mathrm{d}}$ of 5.4 $\times 10^{-8} \mathrm{M}$ and a $B_{\max }$ of $5.9 \mathrm{pmol} / \mathrm{mg}$ BB protein.

The purpose of the current study was to compare toxin $A$ binding and biologic effects in newborn vs. adult rabbit ileum. Binding of biotinylated toxin A and BS- 1 to rabbit ileum from different ages was also examined using immunohistochemical techniques. Inhibition of in vitro protein synthesis and light

1. Abbreviations used in this paper: BB, brush border; BS-1, Bandeira simplicifolia (lectin). 
microscopy was used to assess biologic response to toxin $\mathrm{A}$. We report here that newborn rabbit intestine lacks specific, high-affinity binding sites for toxin $\mathrm{A}$, and is also relatively resistant to the biologic effects of the toxin.

\section{Methods}

\section{Materials}

Bolton-Hunter reagent ( $N$-succinimidyl $\left[2,3-{ }^{3} \mathrm{H}\right]$ propionate; $80 \mathrm{Ci} /$ $\mathrm{mmol}$ ) and $\mathrm{L}-\left[4,5-{ }^{3} \mathrm{H}\right]$ leucine, $130 \mathrm{Ci} / \mathrm{mmol}$ were obtained from Amersham International (Amersham, UK). NHS-LC-Biotin was purchased from Pierce Chemical Co. (Rockford, IL). Streptavidin-biotinylated horseradish peroxidase (HRP) complex was obtained from BioRad Laboratories (Richmond, CA). 4-chloro-1-naphthol (blotting grade) was purchased from Amersham International. Protein concentrations were determined with a protein assay kit (Bradford assay) from Bio-Rad Laboratories, using bovine serum albumin as a standard. Alkaline phosphatase activity in rabbit BB was measured colorimetrically with a kit from Sigma Diagnostics (St. Louis, MO). The isolectin B4 from Bandeirea simplicifolia-I and its biotinylated form and 3,3'diaminobenzidine (DAB) chromogen were purchased from Sigma Diagnostics. Streptavidin-peroxidase conjugate was obtained from Zymed Laboratories Inc. (South San Francisco, CA). New Zealand white rabbits 2-90 d old were obtained from Pine Acres Rabbitry (W. Brattleboro, VT). Animals were fasted overnight before study, but provided with water ad libitum.

\section{Methods}

Toxin purification and radiolabeling. Toxin A was prepared from filtered cultured supernatants of $C$. difficile strain 10463. Toxin A was purified and radiolabeled as described by us (24). Enterotoxic activity of unlabeled and $\left[{ }^{3} \mathrm{H}\right]$ toxin $A$ was assayed in rabbit and rat intestinal loops $(25,26)$ and cytotoxic activity in rat basophilic leukemia cells (24). Typical stock solutions of purified toxin A used in these studies contained between 800 and $2,000 \mu \mathrm{g} / \mathrm{ml}$ protein as measured by Bradford's method (27).

Biotinylation of toxin A. Toxin A was biotinylated using the biotin derivative NHS-LC-biotin by a modification of the method described by Hnatowich et al. (28). Briefly, toxin A in $50 \mathrm{mM}$ bicarbonate buffer ( $\mathrm{pH}$ 8.0) was incubated with NHS-LC-biotin in a 1:20 toxin A to biotin molar to molar ratio for $2 \mathrm{~h}$ on ice. Unreacted reagent was removed by

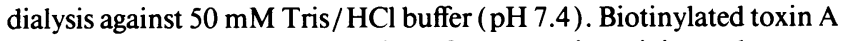
was compared to unlabeled toxin A for cytotoxic activity and enterotoxic activity, and by SDS PAGE according to Laemmli (29) followed by immunoblotting using streptavidin-biotinylated HRP and 4-chloro1 -naphthol as a substrate. Biotinylated toxin A used in these studies migrated identically to native toxin on SDS-PAGE (not shown) and biologic activity against rat basophil leukemia cells (24) and in rat ileal loop assays (26) were identical to native toxin A.

Binding of $\left[{ }^{3} \mathrm{H}\right]$ toxin $A$ to rabbit ileal $B B$. Adult rabbit ileal BB were purified from 10 to $30-\mathrm{cm}$-long ileal segments by the EDTA-chelation method of Hopfer et al. (30). Ileal BB from newborn and infant rabbits ages $2,5,10,14,19$, and $45 \mathrm{~d}$ were purified by $\mathrm{C} \mathrm{CaCl}_{2}$ precipitation method of Israel et al. (31). Purification of BB preparations was assessed by alkaline phosphatase (32), sucrase (33), and lactase (33) activities and by light microscopy of homogenates and purified BB. All purified BB preparations used in this study had a minimum 10-fold enrichment in enzyme activity over the homogenates.

$\mathrm{BB}$ binding experiments were performed in a total volume of $0.2 \mathrm{ml}$ of $50 \mathrm{mM}$ Tris buffer ( $\mathrm{pH} \mathrm{7.4)}$ in assay tubes containing $0.1 \mathrm{mg}$ purified $\mathrm{BB}$ protein as described previously by us (24). For estimation of $\left[{ }^{3} \mathrm{H}\right]$ toxin A specific BB binding at a single unlabeled ligand concentration, binding assays were performed by adding $65 \mathrm{ng}$ to $220 \mu \mathrm{g}$ of $\left[{ }^{3} \mathrm{H}\right]$ toxin $\mathrm{A}(\sim 100,000-200,000 \mathrm{dpm})$ to each tube in the presence or absence of a 200 -fold excess of unlabeled toxin A. In general, nonspecific binding of $\left[{ }^{3} \mathrm{H}\right]$ toxin $A$ in the presence of a 200 -fold excess of unlabeled ligand was $<25 \%$ of total binding in adults and older infants
( 19 and $45 \mathrm{~d}$ old). However, in 2- and 5-d-old rabbit BB nonspecific binding accounted for $>90 \%$ of total binding. For the estimation of the dissociation constant $\left(K_{\mathrm{d}}\right)$ of the toxin A receptor in the 5-d-old rabbit $\mathrm{BB}$, purified $\mathrm{BB}(0.1 \mathrm{mg}$ per tube $)$ were incubated with $\left[{ }^{3} \mathrm{H}\right]$ toxin $\mathrm{A}$ as described above, in the presence of increasing concentrations of unlabeled toxin A to achieve a final concentration of $10^{-9}$ to $10^{-6} \mathrm{M}$. All experiments were performed at $4^{\circ} \mathrm{C}$ for $1 \mathrm{~h}$. Specific $\left[{ }^{3} \mathrm{H}\right]$ toxin $\mathrm{A}$ binding and the apparent $K_{\mathrm{d}}$ of binding was determined as described (24) and data was expressed as picomoles of $\left[{ }^{3} \mathrm{H}\right]$ toxin A bound per milligram of BB protein. In some experiments, BB membranes from a 90-dold rabbit ileum were preincubated with $25 \mu \mathrm{g} / \mathrm{ml}$ of the lectin BS-1 for 60 min at $22^{\circ} \mathrm{C}$ and $\left[{ }^{3} \mathrm{H}\right.$ ] toxin A specific binding was estimated as described previously (24).

Immunohistochemistry. Staining was performed on 5- $\mu \mathrm{m}$ sections of formalin-fixed, paraffin-embedded tissues of normal 5- and 90-d old rabbit ileum. All steps were performed at room temperature. The wash buffer was PBS containing 0.1\% BSA ( $\mathrm{pH} 7.4$ ). Slides were rehydrated with xylene and graded alcohol and then treated with $0.3 \% \mathrm{H}_{2} \mathrm{O}_{2}$ in methanol for $10 \mathrm{~min}$. After washing three times with buffer, slides were incubated with $1 \%$ BSA in PBS for 20 min which was then blotted off. Biotinylated lectin BS-1 $(5 \mu \mathrm{g} / \mathrm{ml})$ or biotinylated toxin A (200 $\mu \mathrm{g} /$ $\mathrm{ml}$ ) were then added for $1 \mathrm{~h}$ followed by three washes. In some experiments 90-d-old formalin-fixed rabbit ileal tissue was first preincubated with $500 \mu \mathrm{g} / \mathrm{ml}$ or $5 \mathrm{mg} / \mathrm{ml}$ of lectin BS- 1 for $60 \mathrm{~min}$ at $22^{\circ} \mathrm{C}$, then washed, and then incubated with biotinylated toxin $\mathrm{A}(200 \mu \mathrm{g} / \mathrm{ml})$. This step was followed by addition of streptavidin-peroxidase ( $10 \mu \mathrm{g} /$ $\mathrm{ml}$ ) for $30 \mathrm{~min}$. After three washes, slides were treated with DAB for 4-6 min, washed extensively with distilled water, counterstained with methyl green, dehydrated, and then mounted. Slides were examined for BS- 1 and toxin A reactivity in a blinded fashion without knowledge of the tissue source.

Protein synthesis in rabbit ileal loops. Ileal loops were constructed in fasted, anesthetized rabbits as previously described $(8,9)$. Two 10$\mathrm{cm}$ loops were formed in each animal, with at least a 5-cm distance between loops. Loops were injected using a 25 -gauge needle with either

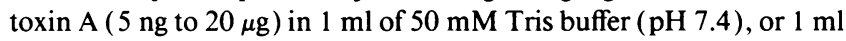
of buffer alone (control). Toxin A was allowed to incubate in the loop for $15 \mathrm{~min}$ while the animal was kept under general anesthesia. Rabbits were then killed with an intravenous bolus of pentobarbital, loops were excised, and mucosal explants measuring $\sim 2 \times 2 \mathrm{~mm}$ were cut with scissors and placed in organ culture dishes. For determination of protein synthesis explants were then incubated with $1.5 \mathrm{ml}$ of Trowell's T-8 medium containing $10 \%$ fetal calf serum, $100 \mathrm{U} / \mathrm{ml}$ penicillin, 100 $\mu \mathrm{g} / \mathrm{ml}$ streptomycin and $10 \mu \mathrm{Ci} / \mathrm{ml}\left[{ }^{3} \mathrm{H}\right]$ leucine. Incorporation of $\left[{ }^{3} \mathrm{H}\right]$ leucine into explant proteins during a 24 -h period at $37^{\circ} \mathrm{C}$ was determined as previously described (34). Results were expressed as disintegrations per minute per milligram of explant protein.

Full thickness samples of ileal explants taken before and after post organ culture were fixed in $10 \%$ phosphate-buffered formalin. After fixation, tissue strips were processed in a VIP-200 tissue processor (Miles Laboratories Inc., Elkhart, IN) and embedded on edge in paraffin. Serial sections were then stained with hematoxylin and eosin and examined by light microscopy.

\section{Results}

Age-related binding of $\left[{ }^{3} \mathrm{H}\right]$ toxin $A$ to rabbit ileal $B B$. As shown in Fig. 1, minimal $\left[{ }^{3} \mathrm{H}\right]$ toxin A specific binding was present in 2- and 5-d old rabbit ileal BB with only 0.01 and 0.02 pmol bound per mg of BB protein, respectively. With increasing age a significant increase of specific toxin A BB binding was observed. BB from 90-d-old rabbits bound $1.83 \mathrm{pmol}$ $\left[{ }^{3} \mathrm{H}\right]$ toxin $\mathrm{A} / \mathrm{mg} \mathrm{BB}$ protein or $\sim 100$-fold more than the levels in BB from 5-d-old rabbits. We have previously reported the presence of high-affinity ( $54 \mathrm{nM}$ ) toxin A receptors in adult rabbit $B B(24)$. In using similar experimental methodology, no 
high affinity receptors for toxin A were identified in the 5-d-old rabbit BB in three separate experiments (data not shown). As expected, preincubation of BB from 90 -d-old rabbit ileum with BS-1 lectin, which binds to terminal $\alpha$-linked galactose residues, significantly reduced $\left[{ }^{3} \mathrm{H}\right]$ toxin A specific binding by $55 \%$ (Fig. 1).

Morphologic localization of bound biotinylated toxin $A$ and $B S-1$. Previous studies have indicated that binding of $\left[{ }^{3} \mathrm{H}\right]$ toxin $A$ toxin $A$ to its intestinal receptor is inhibited by the plant lectin BS-1, which binds to glycoconjugates with terminal $\alpha$-D-galactose residues $(14,24)$. We therefore tested whether the lectin BS-1 would inhibit binding of biotinylated toxin A to adult rabbit ileum. In adult rabbit ileum toxin $A$ reacted strongly with the BB of villus tip cells (Fig. $2 A$ ). Preincubation of rabbit ileum with the lectin BS-1 resulted in marked decrease of toxin A binding (Fig. 2, $B$ and $C$ ), thus confirming the importance of $\alpha$ galactose residues in toxin A receptor.

In that $\left[{ }^{3} \mathrm{H}\right]$ toxin $\mathrm{A}$ binding to ileal $\mathrm{BB}$ was age dependent, we compared toxin A and BS-1 receptor binding in adult vs. neonate rabbit ileum using biotinylated ligands. In 90-d-old rabbit ileum, biotinylated BS-1 (Fig. $3 A$ ) bound to the apical surface of villus and crypt epithelial cells. In addition to its surface location, BS-1 binding was prominent within epithelial cells. Numerous capillary endothelial cells and erythrocytes in the lamina propria and submucosa were also reactive with BS-1 because rabbit erythrocytes are known to have high concentrations of $\alpha$-D-galactose on their surfaces $(35,36)$. In 5-d-old rabbit ileum, BS-1 staining was observed only in the capillaries of the lamina propria, with no visible BB binding (Fig. $3 C$ ). In contrast to BS-1, toxin A binding in 90-d-old intestine (Fig. 3 $B$ ) was limited to the BB of villus tip cells. No binding was observed in 5 day old rabbit ileum when biotinylated toxin A was used as a ligand (Fig. $3 \mathrm{D}$ ).

Age-related inhibition of protein synthesis and intestinal morphology. Previous studies indicated that inhibition of protein synthesis was parallel to cytotoxicity of $C$. difficile toxins $(34,37,38)$. We therefore compared the effect of increasing concentrations of toxin A on protein synthesis and histology in adult and 5-d-old rabbit ileal explants in short-term organ cul-

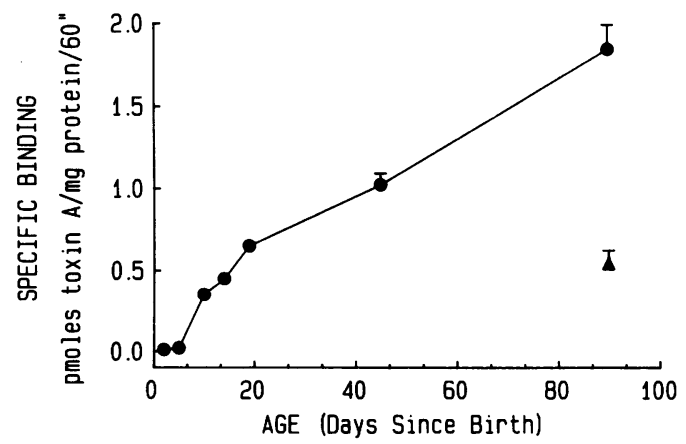

Figure 1. Age-related increase in specific binding of toxin $A$ to rabbit BB. $\left[{ }^{3} \mathrm{H}\right]$ toxin A (10-65 ng, containing 100,000-150,000 dpm) was incubated with $100 \mu \mathrm{g}$ of rabbit ileal BB from 2-90-d-old for 60 $\min$ at $4^{\circ} \mathrm{C}$, in the presence or the absence of a 200 -fold excess of unlabeled toxin $\mathrm{A}$ ( $n=3$ per group). Specific $\left[{ }^{3} \mathrm{H}\right]$ toxin $\mathrm{A}$ binding $(\bullet)$ was calculated as described in Methods. Each point represents the mean \pm standard errors of the mean of three independent experiments for each age. The closed triangle represents $\left[{ }^{3} \mathrm{H}\right]$ toxin $\mathrm{A}$ specific binding to 90 -d-old ileal $\mathrm{BB}$ after preincubation of $\mathrm{BB}$ with 25 $\mu \mathrm{g} / \mathrm{ml}$ of the lectin BS- $1\left(1 \mathrm{~h}, 22^{\circ} \mathrm{C}\right)$ as described in Methods. ture. In these experiments toxin A ( $5 \mathrm{ng}$ to $20 \mu \mathrm{g}$ per loop) was first injected into ileal loops to allow binding to receptors and then mucosal explants were incubated in vitro with $\left[{ }^{3} \mathrm{H}\right]$ leucine to measure protein synthesis. Toxin $\mathrm{A}$ in doses ranging from $50 \mathrm{ng}$ to $20 \mu \mathrm{g}$ per loop significantly inhibited $\left[{ }^{3} \mathrm{H}\right]$ leucine incorporation in adult ileal explants over a period of 24 hours in a dose-dependent fashion (Table I). In contrast, only the two highest concentrations of toxin A ( 5 and $20 \mu \mathrm{g}$ ) significantly inhibited $\left[{ }^{3} \mathrm{H}\right]$ leucine incorporation in 5 -d-old ileal explants. At all doses tested, the inhibitory effect of toxin A on $\left[{ }^{3} \mathrm{H}\right]$ leucine incorporation was less in newborn than adult ileum.

A parallel effect of toxin A on protein synthesis and explant morphology was observed. Adult explants exposed to $5 \mu \mathrm{g}$ of toxin $A$ in vivo and then placed in organ culture for $24 \mathrm{~h}$ showed severe morphologic alterations with necrosis and dehiscence of cells (Fig. 4, lower panel) whereas the 5-d-old ileal explants exposed to the same concentration of toxin A remained relatively normal (Fig. 4, upper panel).

\section{Discussion}

The main finding in these studies is an age-related increase in C. difficile toxin A-receptor binding in newborn vs. adult rabbit BB using biologically active tritiated and biotinylated toxin A (Figs. 1 and 3). Inhibition of toxin A binding with BS-1 (Figs. 1 and 2) confirmed previous reports that the toxin A receptor in rodents contains an $\alpha$-linked galactose residue that binds to this lectin. In addition, staining with biotinylated BS-1, mimicked that of biotinylated toxin $\mathrm{A}$. These results strongly indicate that the intestinal receptor(s) for toxin A and the lectin BS-1 are developmentally regulated.

The age-related appearance of toxin A binding sites was associated with increased toxin responsiveness as assessed by inhibition of protein synthesis (Table I). We have previously reported (8) that high doses of toxin A failed to inhibit protein synthesis when incubated with rabbit ileal explants for $2 \mathrm{~h}$. The diminished protein synthesis at longer exposure times shown in the current study (Table I), probably reflects a response to severe cytoskeletal damage or membrane permeability changes. Inhibition of protein synthesis was used in this study as a measurement of cytotoxicity of toxin A and does not appear to be due to a direct action of this toxin. It would therefore seem more appropriate to demonstrate differences in newborn vs. adult intestine in response to toxin A by assessing cytoskeletal, permeability or secretory alterations, which may represent more specific and earlier effects of the toxin. Although we have attempted to study these effects of toxin A in closed ileal loops of 5-d-old rabbits using methods previously described by us ( 8 , 9), a large percentage of newborns died within $2 \mathrm{~h}$ due to surgical stress making data derived from these studies difficult to interpret. Morphologic evaluation of newborn ileal explants exposed to toxin A showed excellent preservation of architectural and cellular detail, compared to the adult explants which were severely necrotic (Fig. 4). Using biologically active $\left[{ }^{3} \mathrm{H}\right]$ toxin $\mathrm{A}$, we previously demonstrated specific receptors on rabbit ileal $B B$ and RBL cells but absence of measurable binding sites in IMR-90 fibrablasts (24). Because $\left[{ }^{3} \mathrm{H}\right]$ toxin $A$ binding on fibroblasts and RBL cells was well correlated with cytotoxicity (24), we concluded that the toxin A receptors measured in our experiments were physiologically relevant. The 

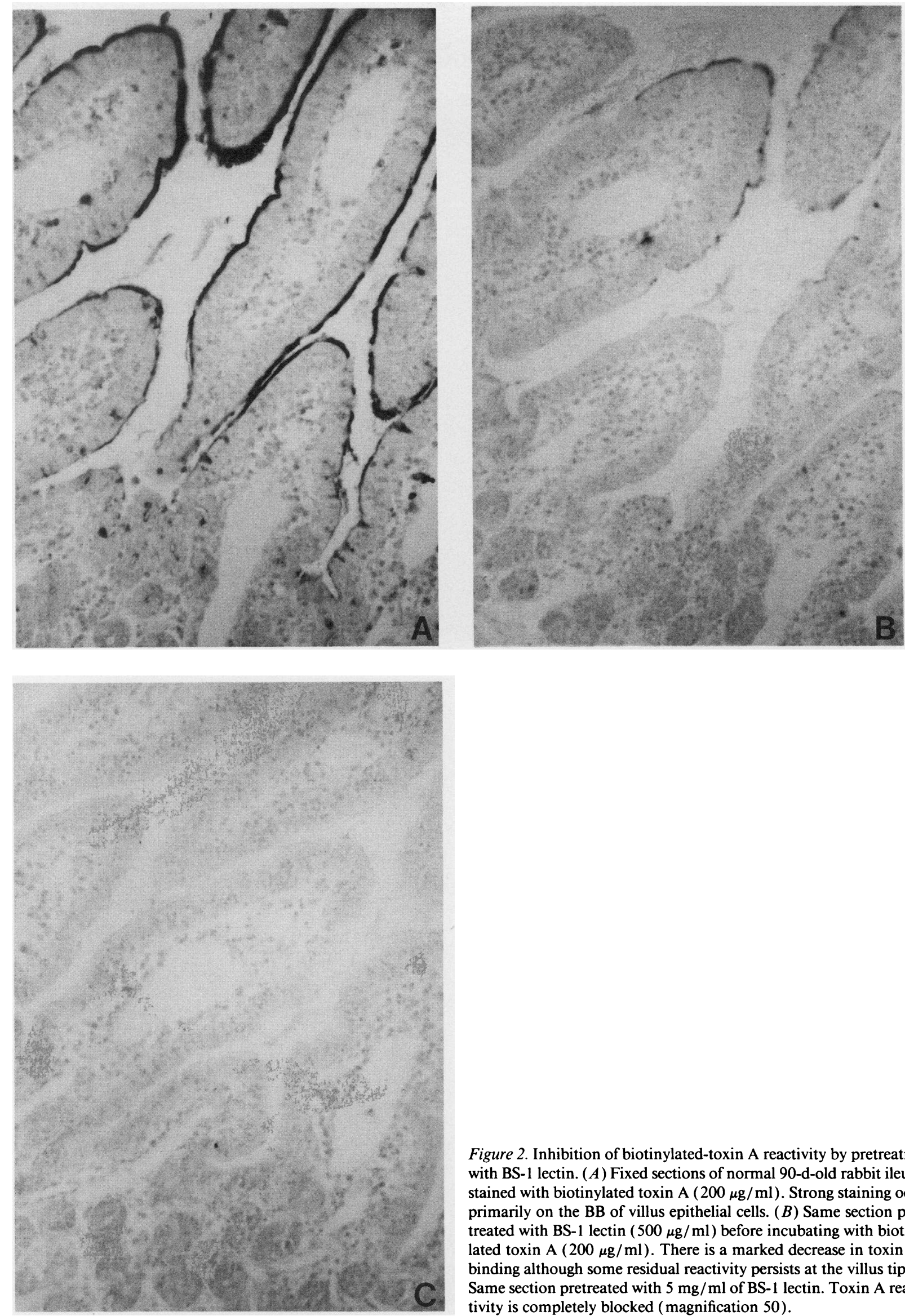

Figure 2. Inhibition of biotinylated-toxin A reactivity by pretreatment with BS-1 lectin. $(A)$ Fixed sections of normal 90-d-old rabbit ileum stained with biotinylated toxin $\mathrm{A}(200 \mu \mathrm{g} / \mathrm{ml})$. Strong staining occurs primarily on the BB of villus epithelial cells. $(B)$ Same section pretreated with BS-1 lectin $(500 \mu \mathrm{g} / \mathrm{ml})$ before incubating with biotinylated toxin $\mathrm{A}(200 \mu \mathrm{g} / \mathrm{ml})$. There is a marked decrease in toxin A binding although some residual reactivity persists at the villus tip. $(C)$ Same section pretreated with $5 \mathrm{mg} / \mathrm{ml}$ of BS-1 lectin. Toxin A reactivity is completely blocked (magnification 50 ). 



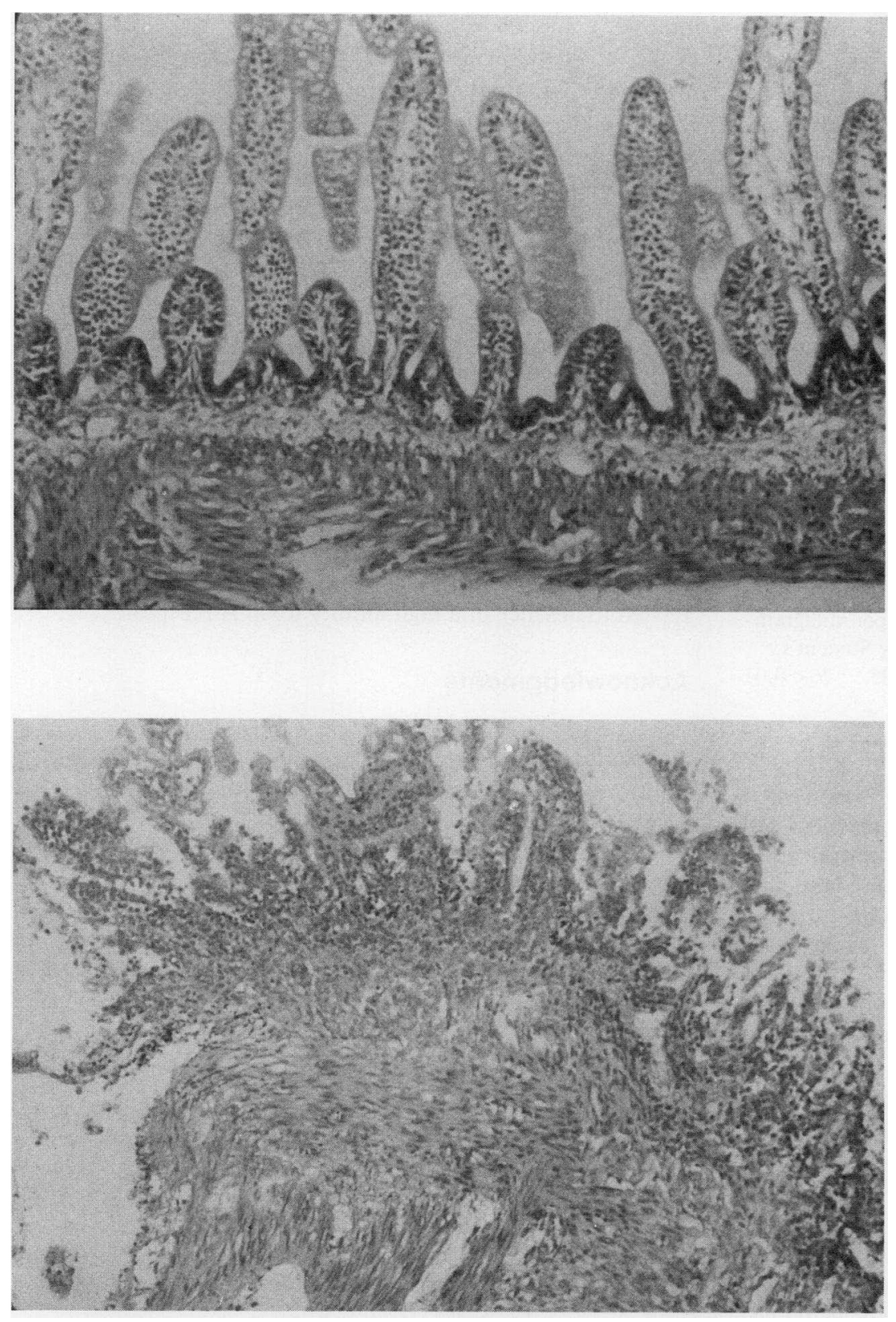

Figure 4. Morphologic effect of toxin A on infant vs. adult rabbit ileal explants. Rabbit ileal loops from 5-d-old (upper panel) or 90-d-old (lower panel) rabbits were injected with $5 \mu \mathrm{g}$ of toxin A and incubated for $15 \mathrm{~min}$. Loops were then excised and ileal explants were placed in organ culture and incubated in medium for $24 \mathrm{~h}$ at $37^{\circ} \mathrm{C}$. At the end of the incubation period full thickness samples of explants were fixed in formalin and processed for light microscopy (magnification 200). temporal relation between toxin A-induced biologic effects and receptor binding activity strongly suggests that the binding activity described in this and previous studies (24) reflects the presence of a functional receptor(s) for toxin A.

Several reports indicate a strong correlation between the age-related expression of membrane receptors for bacterial toxins and responsiveness to enterotoxins. For example, the incidence of shigellosis is relatively low in neonates compared to older children $(39,40)$. In rabbit intestine, receptors for shi- gella toxin are absent at birth, but develop rapidly during the third week of life (20). Appearance of the intestinal shiga toxin receptor, globotriaosylceramide $\left(\mathrm{Gb}_{3}\right)$ was associated with a secretory response to shiga toxin in rabbit ligated ileal loops, while in younger animals who lacked the receptor, no biologic effect of the toxin was noted (20). Another example is provided by the receptor for Escherichia coli heat-stable toxin. Infants and children up to 2 yr of age are relatively more susceptible to toxigenic $E$. coli diarrhea than older children (41).

Figure 3. Age-related binding of biotinylated toxin A or BS-1 to rabbit ileum. Fixed sections of normal 90-d-old $(A$ and $B)$ and 5-d-old $(C$ and $D)$ rabbit ileum were incubated with biotinylated toxin A $(200 \mu \mathrm{g} / \mathrm{ml})$ or biotinylated BS-1 $(5 \mu \mathrm{g} / \mathrm{ml})$. $(A)$ In $90-\mathrm{d}-$ old rabbit ileum, BS-1 binds to epithelial cell cytoplasm in the villus but also to BB of villus and crypt epithelial cells (arrows). Numerous capillaries and erythrocytes in the lamina propria react strongly. $(B)$ Toxin A binds only to the BB of villus epithelium in 90-d-old rabbit ileum. In contrast, epithelial cells of 5-dold rabbit ileum do not react at all with $(C)$ either BS-1 or $(D)$ toxin A, although capillaries and erythrocytes react with BS-1 (magnification 50 ). 
Table I. Differential Inhibition of Protein Synthesis in Newborn vs. Adult Rabbit Ileum by Toxin A

\begin{tabular}{rll}
$\begin{array}{c}\text { Toxin injected } \\
\text { per ileal loop }\end{array}$ & Newborn & Adult \\
\hline & \multicolumn{2}{c}{ percent control } \\
$5 \mathrm{ng}$ & 98.9 & $92.7^{\dagger}$ \\
$50 \mathrm{ng}$ & 97.7 & $84.5^{\dagger \S}$ \\
$500 \mathrm{ng}$ & $96.2^{* \S}$ & $74.4^{* \S}$ \\
$5 \mu \mathrm{g}$ & $75.1^{\dagger}$ & $49.8^{\dagger \mid}$ \\
$20 \mu \mathrm{g}$ & $70.3^{\dagger}$ & $20.2^{\dagger+1}$ \\
\hline
\end{tabular}

Ileal loops from $5 \mathrm{~d}$-old or adult rabbits were injected with $1 \mathrm{ml}$ of 50 $\mathrm{mM}$ Tris containing the indicated concentrations of toxin $\mathrm{A}$ or buffer alone (control) for $15 \mathrm{~min}$ ( $n=3$ for each concentration). Loops were then removed, mucosal explants placed in organ culture and incubated with medium containing $\left[{ }^{3} \mathrm{H}\right]$ leucine for $24 \mathrm{~h}$ at $37^{\circ} \mathrm{C}$. $\left[{ }^{3} \mathrm{H}\right]$ leucine incorporation into explant protein was estimated by radioactivity measurements in TCA precipitates as described in Methods. Data was calculated as disintegrations per minute per milligram of protein, and statistical significance was estimated by Student's $t$ test. ${ }^{*} P<0.05,{ }^{\dagger} P<0.01$ vs. control and ${ }^{\S}<0.05, " ~ P<0.01$ vs. newborn.

Infant intestine from rats (42) and humans (43) possessed a greater number of $E$. coli heat-stable enterotoxin receptors and human infant intestine was more responsive than mature intestine to the effects of heat-stable enterotoxin (44). These data indicate that susceptibility of toxin-mediated diarrhea in infants is related, at least in part, to developmental regulation of specific enterotoxin receptors.

The age-dependent appearance of toxin A binding sites in rabbit ileum may be related to the developmental regulation of receptor peptide synthesis (45) and / or post-translational glycosylation of receptors by glycosyltransferases (46-49). We reported $(50)$ that microsomal galactosyltransferase activity of fetal rat colon increased fourfold between 18 and $22 \mathrm{~d}$ of gestation and then more slowly during neonatal life, reaching adult levels after $14 \mathrm{~d}$. The toxin A receptor in rodents is a glycoconjugate that contains an $\alpha$-linked galactose in or near the toxin binding domain. Conceivably, the diminished toxin A receptor binding activity in neonatal rabbit intestine may be explained by developmental regulation of the specific glycosyltransferase(s) that attach monosaccharides to the receptor peptide. As shown here and other studies $(14,21,24)$ the specific epitope Gal $\alpha$ 1-3Gal $\beta 1-4 \mathrm{GlcNAc}-\mathrm{R}$ appears to be closely related to the biologic effects of the toxin in intestinal and nonintestinal cells. A reasonable assumption to explain our findings is that developmental regulation of the enzyme which catalyzes the synthesis of this oligosaccharide, $N$-acetyllactosaminide $\alpha$ 1-3galactosyltransferase (51), may be responsible for absence of toxin A binding activity in infant rabbits. However, other developmentally regulated steps in toxin A receptor peptide synthesis and surface expression cannot be excluded. For example, the toxin A receptor in adult rabbit ileum and neutrophils is closely associated with membrane $G$ proteins that regulate ligand binding affinity $(24,52,53)$. Thus, it is also possible that immaturity of the $G$ proteins in newborn rabbit ileum may be responsible for diminished toxin A binding in neonatal ileum.

Our data differ from those of Rolfe (54) who reported toxin A receptors in infant hamster $B B$ with similar binding kinetics to those of adults. The dissociation constant $\left(K_{\mathrm{d}}\right)$ reported by Rolfe for the toxin A hamster BB receptor $(66 \mathrm{nM})$ was very similar to the rabbit BB receptor $K_{\mathrm{d}}(54 \mathrm{nM})$ reported by us (24), and binding of toxin A to the hamster BB receptor was also temperature-sensitive, as reported by us (24) and others (14). Species differences are more likely to explain discrepant results in rabbits and hamsters. Despite adequate levels of toxin receptor, infant hamsters appear to be relatively insensitive to the effects of toxin $\mathrm{A}$, in that they can be successfully colonized with toxigenic $C$. difficile with no evidence of intestinal disease (55). This suggests that factors other than receptor density or affinity, for example postreceptor events, may be involved.

In summary, we have shown that the relative absence of specific intestinal binding sites for $C$. difficile toxin A in newborn rabbits is correlated with diminished biologic response to the toxin in this species. Although it is not known at present whether the human intestinal receptor for toxin A is developmentally regulated, our data support the notion that the apparent resistance of human infants to $C$. difficile enteritis may be related to absence of a high-affinity toxin A receptor.

\section{Acknowledgments}

This study was supported in part by a National Research Service Award DK-08395 to Dr. Eglow, and by National Institutes of Health research grants DK-34583 (Dr. LaMont), CA-42581 (Dr. Itzkowitz), and CA42981 (Dr. Itzkowitz). During these studies Dr. Pothoulakis was an American Gastroenterological Association/Glaxo Scholar.

\section{References}

1. Abrams, G. D., M. Allo, G. D. Rifkin, R. Fekety, and J. Silva Jr. 1980. Mucosal damage mediated by clostridial toxin in experimental clindamycin-associated colitis. Gut. 21:493-499.

2. Bartlett, J. G., A. B. Onderdonk, R. L. Cisneros, and D. L. Kasper. 1977. Clindamycin-associated colitis due to a toxin-producing species of Clostridium in hamsters. J. Infect. Dis. 136:701-705.

3. George, W. L., R. D. Rolfe, and S. M. Finegold. 1982. Clostridium difficile and its cytotoxin in feces of patients with antimicrobial agent associated diarrhea and miscellaneous conditions. J. Clin. Microbiol. 15:1049-1053.

4. Bartlett, J. G., W. Chang, M. Gurwith, S. L. Gorbach, and A. B. Onderdonk. 1978. Antibiotic-associated pseudomembranous colitis due to toxin-producing clostridia. N. Engl. J. Med. 298:531-534.

5. McFarland, L. V., M. E. Maury, R. Y. Y. Kwok, W. E. Stamm. 1989. Nosocomial acquisition of Clostridium difficile infection. N. Engl. J. Med. 320:204-210.

6. Dove, C. H., S.-Z. Wang, S. B. Price, C. J. Phelps, D. M. Lyerly, T. D. Wilkins, and J. L. Johnson. 1990. Molecular characterization of the Clostridium difficile toxin A gene. Infect. Immun. 58:480-488.

7. Mitchell, T. J., J. M. Ketley, S. C. Haslam, J. Stephen, D. W. Burdon, D. C. A. Candy, and R. Daniel. 1986. Effect of toxins A and B of Clostridium difficile on rabbit ileum and colon. Gut. 27:78-85.

8. Triadafilopoulos, G., C. Pothoulakis, M. J. O'Brien, and J. T. LaMont 1987. Differential effects of Clostridium difficile toxins A and B on rabbit ileum. Gastroenterology. 93:273-279.

9. Triadafilopoulos, G., C. Pothoulakis, R. Weiss, C. Giampaolo, and J. T. LaMont. 1989. Comparative study of Clostridium difficile toxin A and cholera toxin in rabbit ileum. Gastroenterology. 97:1186-1192.

10. Moore, R., C. Pothoulakis, J. T. LaMont, S. Carlson, and J. L. Madara 1990. Clostridium difficile toxin A exerts neutrophil-independent effects on intestinal epithelial structure and function. Am. J. Physiol. 259:(Gastrointest. Liver Physiol.):G165-G172.

11. Hecht, G., C. Pothoulakis, J. T. LaMont, and J. L. Madara. 1988. Clostridium difficile toxin A perturbs cytoskeletal structure and junction permeability in cultured human epithelial cells. J. Clin. Invest. 82:1516-1524.9.

12. Sullivan, N. M., S. Pellet, and T. D. Wilkins. 1982. Purification and characterization of toxin A and B from Clostridium difficile. Infect Immun. 35:1032-1040.17.

13. Thelestam, M., and I. Florin. 1984. Cytopathogenic action of Clostridium difficile toxins. J. Toxicol. 3:139-180.

14. Krivan, H., C. F. Clark, D. F. Smith, and T. D. Wilkins. 1986. Cell surface 
binding site for Clostridium difficile enterotoxin: evidence for a glycoconjugate containing the sequence $\mathrm{Gal}$ alpha $1-3 \mathrm{Gal}$ beta-4GlcNAc. Infect. Immun. 53:573-581.

15. Lyerly, D. M., K. E. Saum, D. McDonaldand, and T. D. Wilkins. 1986. Effect of toxins A and B given intragastrically to animals. Infect. Immun. 47:349352.

16. Donta, S. T., and M. G. Mayers. 1982. Clostridium difficile toxin in asymptomatic neonates. J. Pediatr. 100:431-434.

17. Al-Jumaili, I. J., M. Shibley, A. H. Lishman, and C. O. Record. 1984 Incidence and origin of Clostridium difficile in neonates. J. Clin. Microbiol. 19:77-78.

18. Stark, P. L., A. Lee, and B. D. Parsonage. 1982. Colonization of the large bowel by Clistridium difficile in healthy infants: quantitative study. Infect. Immun. 35:895-899.

19. Lyerly, D. M., H. C. Krivan, and T. D. Wilkins. 1988. Clostridium diffcile: Its disease and toxins. Clin. Microbiol. Rev. 1:1-18.

20. Mobassaleh, M., A. Donohue-Rolfe, M. Jacewicz, R. J. Grand, and G. T. Keusch. 1988. Pathogenesis of Shigella diarrhea: evidence for a developmentally regulated glycolipid receptor for Shigella toxin involved in the fluid secretory response of rabbit small intestine. J. Infect. Dis. 157:1023-1031.

21. Wilkins, T. D., and K. D. Tucker. 1989. Clostridium difficile toxin A (enterotoxin) uses $\mathrm{Gal}$ alpha 1-3Gal beta $1-4 \mathrm{GlcNAC}$ as a functional receptor. Microecol. Ther. 19:225-227.

22. Henriques, B., I. Florin, and M. Thelestam. 1987. Cellular internalization of Clostridium difficile toxin A. Microb. Pathogen. 2:455-463.

23. Clark, G. F., H. C. Krivan, T. D. Wilkins, and D. F. Smith. 1987. Toxin A from Clostridium difficile binds to rabbit erythrocyte glycolipids with terminal Gal alpha 1-3Gal beta 1-4GlcNAc sequences. Arch. Biochem. Biophys. 257:217229.

24. Pothoulakis, C., J. T. LaMont, E. Eglow, N. Gao, J. F. Rubbins, T. C. Theoharides, and B. F. Dickey. 1991. Characterization of rabbit ileal receptors for Clostridium difficile toxin A: evidence for a receptor-coupled G-protein. J. Clin. Invest. 88:119-125.

25. De, S. N., and D. N. Chatterge. 1953: An experimental study on the mechanism of action of Vibrio cholerae on the intestinal mucus membrane. $J$. Pathol. Bacteriol. 66:559-562.

26. Torres, J., E. Jennische, S. Lange, and I. Lonnroth. 1990. Enterotoxins from Clostridium difficile: diarrhoegenic potency and morphological effects in the rat intestine. Gut. 31:781-785.

27. Bradford, M. 1979. A rapid and sensitive method for the quantitation of microgram quantities of protein utilizing the principle of protein dye binding. Anal. Biochem. 72:248-254.

28. Hnatowitch, D. J., F. Virzi, and M. Rusckowski. 1987. Investigations of avidin and biotin for imaging applications. J. Nucl. Med. 28:1294-1302.

29. Laemmli, U. K. 1970. Cleavage of structural proteins during the assembly of the head of bacteriophage $\mathrm{T}_{4}$. Nature (Lond.). 227:680-685.

30. Hopfer, U., K. Nelson, J. Perrotto, and K. J. Isselbacher. 1973. Glucose transport in isolated brush border membrane from rat small intestine. J. Biol. Chem. 248:25-32.

31. Israel, E. J., K. Y. Pang, T. R. Harmatz, and W. A. Walker. 1987. Structural and functional maturation of rat gastrointestinal barrier with thyroxin. $\mathrm{Am}$. J. Physiol. 252:G762-G767.

32. Bessey, O. A., O. H. Lowry, and M. J. Brook. 1946. A method for the rapid determination of alkaline phosphatase with five cubic millimeters of serum. $J$. Biol. Chem. 71:324-329.

33. Dahlquist, A. 1964. Method for assay of intestinal dissacharides. Anal. Biochem. 7:18-25.

34. Pothoulakis, C., G. Triadafilopoulos, M. Klark, C. Franzblau, and J. T. LaMont. 1986. Clostridium difficile toxin B inhibits protein synthesis in fibroblasts and intestinal mucosa. Gastroenterology. 91:1147-1153.
35. Eto, T., Y. Ichikawa, K. Nishimura, S. Ando, and T. Yamakawa. 1968. Chemistry of lipid of the posthemolytic residue or stroma of erythrocytes. XVI. Occurence of ceramide pentasaccharide in the membrane of erythrocytes and reticulocytes of rabbit. J. Biochem. 64:205-213.

36. Handfland, P., H. Egge, U. Dabrowski, S. Kuhn, D. Roelke, and J. Dabrowski. 1981. Isolation and characterization of an I-active ceramide decasaccharide from rabbit erythrocyte membranes. Biochemistry. 20:5310-5319.

37. Rothman, S. W., J. E. Brown, A. Diecidue, and D. A. Foret. 1984. Differential cytotoxic effects of toxins $\mathrm{A}$ and $\mathrm{B}$ isolated from Clostridium difficile. Infect. Immun. 46:324-331.

38. Florin, I., and M. Thelestam. 1981. Intoxication of cultured lung fibroblasts with Clostridium difficile toxin. Infect. Immun. 33:67-74.

39. Marcy, S. M., R. L. Guerrant. 1983. Shigella. In Infectious Diseases of the Fetus and Newborn infant. J. S. Remington, and J. O. Klein, editors. Philadelphia: W. B. Saunders Co.

40. Starke, J. R., and C. J. Baker. 1985. Neonatal Shigellosis with bowel perforation. Pediatr. Infect. Dis. J. 4:405-407.

41. Guerrant, R. L., R. A. Moore, P. M. Kirschenfeld, and M. A. Sande. 1975. Role of toxigenic and invasive bacteria in acute diarrhea in childhood. $N$. Engl. J. Med. 293:567-573.

42. Cohen, M. B., M. S. Moyer, M. Luttrell, and R. A. Giannella. 1986. The immature rat small intestine exhibits an increased sensitivity and response to Escherichia coli heat-stable enterotoxin. Pediatr. Res. 20:555-560.

43. Cohen, M. B., A. Guarino, R. Shukla, and R. Giannella. 1988. Age-related differences in receptors for Escherichia coli heat-stable enterotoxin in the small and large intestine of children. Gastroenterology. 94:367-373.

44. Guarino, A., M. B. Cohen, and R. A. Giannella. 1987. Small and large intestinal guanylate cyclase activity in children: effect of age and stimulation by Escherichia coli heat-stable enterotoxin. Pediatr. Res. 21:551-555.

45. Gordon, J. I., N. Elshourbagy, J. B. Lowe, W. S. Liao, D. Alpers, and J. M. Taylor. 1985. Tissue specific expression and developmental regulation of two genes encoding for rat fatty acid binding proteins. J. Biol. Chem. 260:1995-1998.

46. Chu, S. W., and W. A. Walker. 1986. Developmental changes in the activities of sialyl-and fucosyltransferases in rat small intestine. Biochim. Biophys. Acta. 883:496-500.

47. Ozaki, C. K., S-H. W. Chu, and A. Walker. 1989. Developmental changes in the galactosyltransferase activity in the rat small intestine. Biochim. Biophys. Acta. 991:243-247.

48. Biol, M. C., M. M. Richard, and P. Louisot. 1987. Developmental changes in intestinal glycosyltransferase activity. Pediatr. Res. 2:250-257.46.

49. Paulson, J. C., and K. J. Colley. 1989. Glycosyltransferases. Structure, localization, and control of type-specific glycosylation. J. Biol. Chem. 264:17615-17618.

50. Rampal, P., J. T. LaMont, and J. S. Trier. 1978. Differentiation of glycoprotein synthesis in fetal rat colon. Am. J. Physiol. 235:E207-E212.

51. Galili, U., S. B. Shohet, E. Kobrin, C. L. M. Stuls, and B. A. Macher. 1988. Man, Apes, and Old World monkeys differ from other mammals in the expression of alpha-galactosyl epitopes on nucleated cells. J. Biol. Chem. 263:1775517762.

52. Pothoulakis, C., R. Sullivan, D. A. Melnic, G. Triadafilopoulos, A. S. Gadenne, T. Meshulam, and J. T. LaMont. 1988. Clostridium difficile toxin A stimulates intracellular calcium release and chemotactic response in human granulocytes. J. Clin. Invest. 81:1741-1745.28.

53. Becker, S. D., C. Pothoulakis, B. F. Dickey, and J. T. LaMont. 1989. Clostridium difficile toxin A binds to a G-protein coupled receptor on rabbit neutrophils. Gastroenterology. 96:A36.(Abstr.)

54. Rolfe, R. D. 1991. Binding kinetics of Clostridium difficile toxins A and B to intestinal brush border membranes from infant and adult hamsters. Infect. Immun. 59:1223-1230.

55. Rolfe, R. D., and J. P. Iaconis. 1983. Intestinal colonization of infant hamsters with Clostridium difficile toxins. Infect. Immun. 42:480-486. 